\title{
Protective effect of Rhododendron weyrichii flower extract against UVB-induced proinflammatory cytokine production in human keratinocytes
}

\author{
Eun-Jin Yang ${ }^{1}$, Suk Hyun Yun ${ }^{1}$, Ji-Hye Ko ${ }^{1}$, Hyun-Kyu Kang ${ }^{1}$, Jung No Lee², Sung-Min Park ${ }^{2}$, Chang-Gu Hyun 1,* \\ ${ }^{1}$ Department of Chemistry and Cosmetics, Jeju National University, Jeju 63243, Korea. \\ ${ }^{2}$ R\&D Center, CoSeedBioPham Co., Chungbuk 28161, Korea.
}

\section{ARTICLE INFO \\ Article history: \\ Received on: 20/06/2018 \\ Accepted on: 19/07/2018 \\ Available online: 31/01/2019}

\section{Key words:}

UVB, Rhododendron

weyrichii, IL-6 and TNF-a,

kaempferol and astragalin.

\begin{abstract}
Ultraviolet B (UVB) radiation is harmful to the skin and induces cytokine release from keratinocytes leading to inflammatory skin disorders. Previous studies have shown that chronic exposure to UVB radiation increases tumor necrosis factor (TNF)- $\alpha$ and interleukin (IL)-6 secretion through various signaling pathways, resulting in skin inflammation and increased risk of skin cancer. The present study was undertaken to investigate the protective effects of Rhododendron weyrichii flower (RWF) extracts against UVB damage of immortalized human keratinocytes (HaCaT). To determine the anti-inflammatory effects of RWF, we examined UVB-induced proinflammatory cytokine production in $\mathrm{HaCaT}$ cells in the presence or absence of RWF extract, using enzyme-linked immunosorbent assay (ELISA). The results indicated that the RWF extract inhibited the production of proinflammatory molecules such as IL- 6 and TNF- $\alpha$, but not IL-8, in UVB-irradiated HaCaT cells. These results demonstrate that RWF potentially protects against UVB-induced skin inflammation. In addition, using high-performance liquid chromatography (HPLC) fingerprinting, kaempferol $(0.335 \mathrm{ppm})$ and astragalin $(2.569 \mathrm{ppm})$ were identified and quantified as RWF extract constituents. Moreover, we tested the potential application of RWF extracts as a cosmetic treatment by performing human skin primary irritation tests. In these tests, the RWF extracts did not induce adverse reactions. Based on these results, we suggest that RWF extracts be considered anti-inflammatory candidates for pharmaceutical and/or cosmetic applications.
\end{abstract}

\section{INTRODUCTION}

The skin is the largest organ in the body and serves as a primary defense against a harmful environment that includes pathogens and ultraviolet (UV) light. Although UV radiation is necessary for the biosynthesis of vitamin $\mathrm{D}_{3}$ to promote bone formation, the induction of melanogenesis for photoprotection, and as a treatment for vitiligo and psoriasis, its acute exposure is a major risk factor for skin inflammation, skin aging, and skin cancer (Kim et al., 2013; Kim et al., 2015). Human keratinocytes are found in the epidermal layer of the skin and play an important role in the inflammatory response to a variety

${ }^{*}$ Corresponding Author

Chang-Gu Hyun, Department of Chemistry and Cosmetics, Jeju

National University, Jeju 63243, Korea.

E-mail:cghyun@jejunu.ac.kr of stress stimuli such as UV radiation. There are three types of UV rays, UVA, UVB, and UVC. Of these, UVC cannot pass through the ozone layer of the earth and has little effect on the skin, but humans are exposed to UVA and UVB, inducing melanin pigmentation that causes skin tanning and spotting, and potentially leading to skin damage, wrinkling, and cancer (Ha et al., 2016; Park et al., 2017). Among the UV wavelengths, UVB $(290-315 \mathrm{~nm})$ radiation also increases the production of some proinflammatory cytokines such as tumor necrosis factor-alpha (TNF- $\alpha$ ), interleukin (IL)-6, and IL-8, from human keratinocytes, leading to skin inflammation. Because TNF- $\alpha$, IL-6, and IL-8 are specifically upregulated in the epidermis as a result of chronic exposure to UVB radiation, the levels of proinflammatory cytokines may serve as early markers of acute skin inflammation (Kim et al., 2018; Janda et al., 2016; Lembo et al., 2014; Krolikiewicz-Reniml et al., 2013). 
There are 11 species and 2 varieties of Rhododendron weyrichii Maxim on the Korea Peninsula including North Korea. It is known that $R$. weyrichii is native to Jeju in Korea and is distributed in the southern part of Japan. $R$. weyrichii is a deciduous shrub that grows 3-6 $\mathrm{m}$ high on the mountainside of Mt. Halla up to $1.200 \mathrm{~m}$ above sea level (Yoichi et al., 2016). The leaves at the ends of the branches are trilobed with dark green and brown hairs on their surface. The antioxidant, anti-inflammatory, and skin-whitening effects of the leaves of $R$. weyrichii have been noted (Kim, 2015). Recently, our laboratory has also reported that extracts of the $R$. weyrichii flower can be used as skin-whitening agents because they inhibit melanin formation by suppressing the proteins involved in melanogenesis (Kim et al., 2016). In addition, there was a study promoting the whitening effect of rhododendrol, a natural substance that is commonly found in Rhododendron plants and has a similar structure to that of arbutin. However, some patients using brightening/lightening cosmetics containing rhododendrol unexpectedly developed leukoderma. Most of the patients developed leukoderma at the site of repeated rhododendrol application, but some patients also showed white patches at remote sites (Ito and Wakamatsu, 2018; Yoshikawa et al., 2016; Inoue et al., 2016).

Although published evidence suggests that $R$. weyrichii has promising biological effects against various diseases, its effect on UVB-induced skin inflammation and the mechanisms responsible remain unclear. Therefore, this study was designed to explore the anti-inflammatory activity of $R$. weyrichii extracts by measuring their effects on proinflammatory cytokine secretion from UVB-irradiated $\mathrm{HaCaT}$ keratinocytes. In addition, potential active components of the extracts were identified by HPLC analysis, and tolerability was confirmed using skin irritation tests. To the best of our knowledge, this is the first report of the antiinflammatory biological activity of $R$. weyrichii in UVB-irradiated HaCaT keratinocytes.

\section{MATERIALS AND METHODS}

\section{Materials and solvent extraction}

$R$. weyrichii flowers (RWFs) were collected from Daejung (a region on Jeju Island, Korea) in May 2017. The materials for extraction were air-dried and then ground into a fine powder using a blender. The dried powder $(20 \mathrm{~g})$ was extracted with $70 \%$ ethanol $(\mathrm{EtOH} ; 600 \mathrm{~mL})$ at room temperature for $24 \mathrm{~h}$ and then evaporated under vacuum. The yield and recovery of the RWF extracts were $5.78 \mathrm{~g}$ and $9.63 \%$, respectively.

\section{Cell culture and UVB irradiation}

Immortalized human keratinocyte $\mathrm{HaCaT}$ cells were cultured in Dulbecco's modified Eagle medium (DMEM) containing $10 \%$ fetal bovine serum (FBS) and $1 \%$ antibiotics $(100$ $\mathrm{U} / \mathrm{mL}$ penicillin and $100 \mu \mathrm{g} / \mathrm{mL}$ streptomycin) in a humidified incubator at $37^{\circ} \mathrm{C}$ and $5 \% \mathrm{CO}_{2}$. HaCaT cells were irradiated by $\mathrm{UVB}$ at $25 \mathrm{~mJ} / \mathrm{cm}^{2}$ using a UV lamp with a peak emission of 312 nm (Vilber Lourmat, BLX-312, Marne-la-Vallée, France). The $\mathrm{HaCaT}$ cells were rinsed with phosphate-buffered saline (PBS), and irradiation was performed with the cells under PBS. After UVB irradiation, the cells were incubated in fresh DMEM for 24 h.

\section{Cell viability assay}

Cell viability in the presence of RWF was determined using the colorimetric 3-(4,5-dimethylthiazol-2-yl)-2, 5-diphenyl2H-tetrazolium bromide (MTT) assay. HaCaT cells were seeded at $5 \times 10^{4}$ cells per well in 24-well plates and were treated with various concentrations of RWF extract $(50,100,200$, or $400 \mu \mathrm{g} /$ $\mathrm{mL}$ ) for $24 \mathrm{~h}$. Then, the media in all wells was replaced with MTT solution $(5 \mathrm{mg} / \mathrm{mL})$ and the plates were incubated for $4 \mathrm{~h}$ at $37^{\circ} \mathrm{C}$. Finally, the MTT-containing medium was removed by aspiration and $1 \mathrm{~mL}$ of dimethyl sulfoxide (DMSO) was added to each well. The absorbance was measured at $540 \mathrm{~nm}$ using a Tecan sunrise microplate reader (Tecan Trading AG, GrÖdlg, Austria).

\section{Enzyme-linked immunosorbent assay (ELISA)}

$\mathrm{HaCaT}$ cells were seeded in 24-well plates at a density of $5 \times 10^{4}$ cells per well for the determination of TNF- $\alpha$, IL- 8 , and IL-6 levels. After $24 \mathrm{~h}$, the cells were irradiated with $25 \mathrm{~mJ} / \mathrm{cm}^{2}$ UVB (as described in the cell culture and UVB irradiation section above) and treated with various concentrations of RWF extract $(100,200$, or $400 \mu \mathrm{g} / \mathrm{mL})$ in DMEM medium for $24 \mathrm{~h}$. The culture supernatants were harvested, and the levels of the cytokines were measured using ELISA kits (R\&D Systems, MN, USA).

\section{HPLC fingerprinting of RWF extracts}

The RWF extracts were brought to a concentration of 1 $\mathrm{mg} / \mathrm{mL}$ and filtered through a $0.22-\mu \mathrm{m}$ membrane filter (Millipore, Bedford, MA, USA). The kaempferol and astragalin analyses were carried out using HPLC (Waters e2695 and 2489 UV Detector). The analysis was performed on a YMC-Triart C18 (5 $\mu \mathrm{m}, 250 \times$ 4.6 mm ID) column (YMC Europe GmbH, Dinslaken, Germany). Kaempferol was eluted with a mobile phase of $40 \%$ A (acetonitrile) and $60 \% \mathrm{~B}$ (20 mM phosphoric acid); the wavelength of the UV detector was $370 \mathrm{~nm}$. Astragalin was eluted with $30 \% \mathrm{~A}$ and $70 \% \mathrm{~B}$; the wavelength of the UV detector was $264 \mathrm{~nm}$. For both compounds, the flow rate was $1.0 \mathrm{~mL} / \mathrm{min}$, column temperature was $37^{\circ} \mathrm{C}$, and the injection volume was $10 \mu \mathrm{L}$. Calibration curves of known concentrations were used for quantification of the compounds in the extracts.

\section{Human skin primary irritation test}

This study was conducted by adopting a $48 \mathrm{~h}$ single patch test using the guidelines proposed by the Personal Care Products Council (PCPC). This test was conducted in accordance with the PCPC Guidelines for the purpose of contributing to the development of safe cosmetics by anticipating side effects that may be caused by cosmetics. The subjects were healthy, nonsmoking women of Korean origin. Thirty-one subjects participated in the entire course of the test. The mean age of the subjects was 40.32 \pm 7.60 years, the highest age was 50, and the lowest age was 23 . The test site was washed with $70 \%$ ethanol and then dried. The test substance was diluted to $200 \mu \mathrm{g} / \mathrm{mL}$ in squalane. Sixteen microliters of the diluted test substance were placed into the Finn chamber (SmartPractice, Denmark), situated on the back of the test site, and fixed with Micropore ${ }^{\mathrm{TM}}$ tape (3M/Medical-Surgical Division, USA). After $48 \mathrm{~h}$, removing the patches, the test area was marked with a skin marker (Chemotechnique Diagnostics AB, Sweden), and the test sites were observed after at $30 \mathrm{~min}$ and 24 $\mathrm{h}$. The skin response was evaluated in accordance with the Frosch 
and Kligman rules. The evaluation results were calculated after 48 $\mathrm{h}$ and $72 \mathrm{~h}$ using the equation below. The average reactivity for $400 \mu \mathrm{g} / \mathrm{mL}$ RWF extract was assessed according to the criteria in Table 1.

$$
\text { Response }=\frac{\sum(\text { Grade } \times \text { No. of Responders })}{4 \text { (Maximum grade }) \times n(\text { Total Subjects })} \times 100 \times 1 / 2
$$

Table 1: Human primary irritation index for cosmetic products.

\begin{tabular}{cc}
\hline Range of Response & Criteria \\
\hline $0.00 \leq \mathrm{R}<0.87$ & Slight \\
$0.87 \leq \mathrm{R}<2.42$ & Mild \\
$2.42 \leq \mathrm{R}<3.44$ & Moderate \\
$3.44 \leq \mathrm{R}$ & Severe \\
\hline
\end{tabular}

$\mathrm{R}$ : response range.

\section{RESULTS AND DISCUSSION}

Numerous studies have indicated that proinflammatory cytokines such as IL- 6 , TNF- $\alpha$, and IL- 8 play a role in the immunological regulation of human skin, including skin inflammation. In order to validate the use of RWF extracts as antiinflammatory agents, we investigated the effects of RWF extracts on the production of IL- 6 , TNF- $\alpha$, and IL- 8 in UVB-irradiated $\mathrm{HaCaT}$ keratinocyte cells. First, we evaluated the effect of RWF on $\mathrm{HaCaT}$ cell viability after $24 \mathrm{~h}$ treatment using an MTT assay. Treatment with RWF extracts at a concentration of 100 to 400 $\mu \mathrm{g} / \mathrm{mL}$ for $24 \mathrm{~h}$, rather than reduce cell viability, significantly increased it instead (Fig. 1). UVB irradiation alone dosedependently reduced the viability of the $\mathrm{HaCaT}$ keratinocyte cells (data not shown). As shown in Fig. 2, UVB irradiation of $25 \mathrm{~mJ} /$ $\mathrm{cm}^{2}$ significantly reduced the viability of the $\mathrm{HaCaT}$ keratinocyte cells. However, following treatment with various concentrations of RWF extracts (from 100 to $400 \mu \mathrm{g} / \mathrm{mL}$ ), the cell viability was increased in a concentration-dependent manner. Therefore, RWF extracts at a concentration of $400 \mu \mathrm{g} / \mathrm{mL}$ normalized the cell growth inhibition of UVB-treated HaCaT keratinocyte cells, with the cell viability closely approaching that of non-UVB-treated control cells.

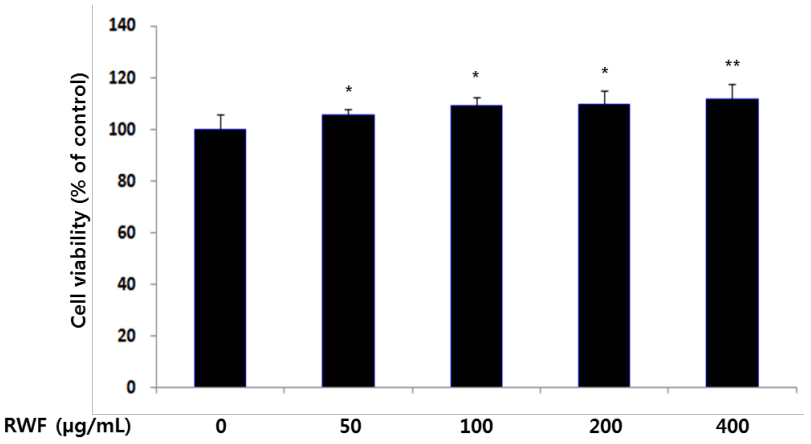

Fig. 1: Cytotoxicity of various concentrations of Rhododendron weyrichii flower (RWF) extracts on HaCaT cells. The cells were treated with 50, 100, 200 , or $400 \mu \mathrm{g} / \mathrm{mL}$ of RWF extract for $24 \mathrm{~h}$, and then the cell viability was measured by MTT assay. The data represent the means \pm SD of quadruplicate experiments. ${ }^{*} \mathrm{p}<0.05, * * \mathrm{p}<0.01$ compared to $0 \mu \mathrm{g} / \mathrm{mL}$ RWF concentration.

As aforementioned, IL-6, TNF- $\alpha$, and IL-8 undoubtedly play pivotal roles in immunologic regulation in human skin and are involved in skin inflammation. Therefore, the inhibition of IL- 6 , TNF- $\alpha$, and IL- 8 would be expected to have favorable anti-inflammatory effects on skin diseases. Thus, we determined the inhibitory effect of RWF extract on IL-6, TNF- $\alpha$, and IL-8 production in UVB-irradiated HaCaT keratinocyte cells. The cells were pretreated with RWF extracts (from 100 to $400 \mu \mathrm{g} / \mathrm{mL}$ ) prior to irradiation with UVB $\left(25 \mathrm{~mJ} / \mathrm{cm}^{2}\right)$ for $24 \mathrm{~h}$ and then analyzed by ELISA. As shown in Fig. 3, the levels of IL-6 (Fig. 3A) and TNF- $\alpha$ (Fig. 3B) were considerably increased in $\mathrm{HaCaT}$ cells after UV-B irradiation. Pretreatment of the cells with RWF extracts (from 100 to $400 \mu \mathrm{g} / \mathrm{mL}$ ) inhibited these upregulations in a concentrationdependent and statistically significant manner. In contrast, the RWF extracts did not inhibit IL-8 production in UVB-irradiated HaCaT keratinocyte cells (Fig. 3C). These results provide direct evidence to show that RWF extracts act as inhibitory agents against IL- 6 and TNF- $\alpha$ production.

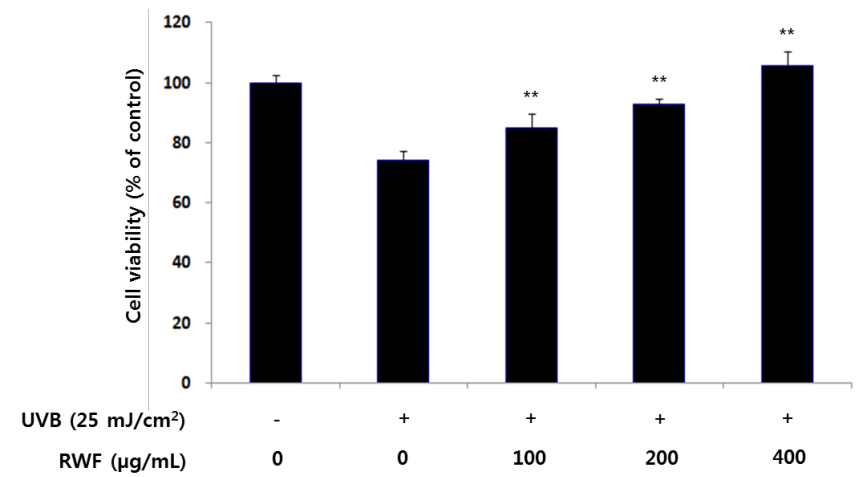

Fig. 2: Effect of Rhododendron weyrichii flower (RWF) extract on cell viability in UVB-irradiated HaCaT cells. The cells were treated with or without RWF extract and then irradiated with UVB $\left(25 \mathrm{~mJ} / \mathrm{cm}^{2}\right)$. After $24 \mathrm{~h}$, the cell viability was measured by MTT assay. The data represent the means $\pm \mathrm{SD}$ of quadruplicate experiments. $* * p<0.01$ compared to UVB alone.

The identification of isolated compounds is very important for the development of functional materials using natural extracts. With the development of analytical technology, chromatographic methods are highly recommended for developing fingerprints of natural raw materials (Kim et al., 2014; Yoon et al., 2009) Therefore, a simple HPLC fingerprint of the plant extract was explored in this study. Since kaempferol and astragalin have been reported as constituents of the Rhododendron plant with effective anti-inflammatory activities, their content in the extracts was measured (Wang et al., 2015; Mok et al., 2013). Using the conditions described in the Materials and Methods section, both kaempferol (Fig. 4A) and astragalin (Fig. 4B) were well resolved from the RWF extract with excellent peak shapes. The contents of kaempferol and astragalin in the ethanol extract were 0.335 and 2.569 ppm, respectively (Fig. 4).

Finally, we tested the potential application of RWF extract as a cosmetic material by performing human skin primary irritation tests to exclude adverse skin reactions. As shown in Table 2 , all of the 31 volunteers experienced no severe adverse reactions after RWF extract treatment. Considering these results, we suggest that RWF extracts be considered anti-inflammatory candidates for topical applications. The inhibition of pro-inflammatory cytokines in keratinocytes offers new therapeutic strategies for the treatment of skin inflammation. Further research is required to purify and identify novel active compounds and to determine other biomarkers of UVB-induced skin-inflammation. 


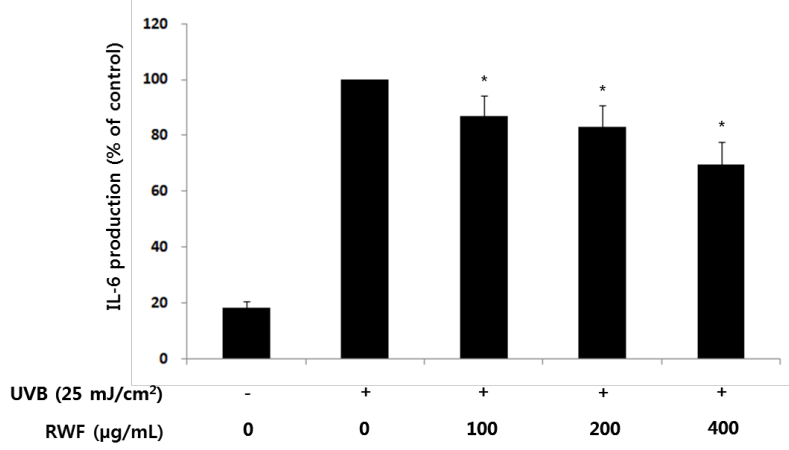

(A)

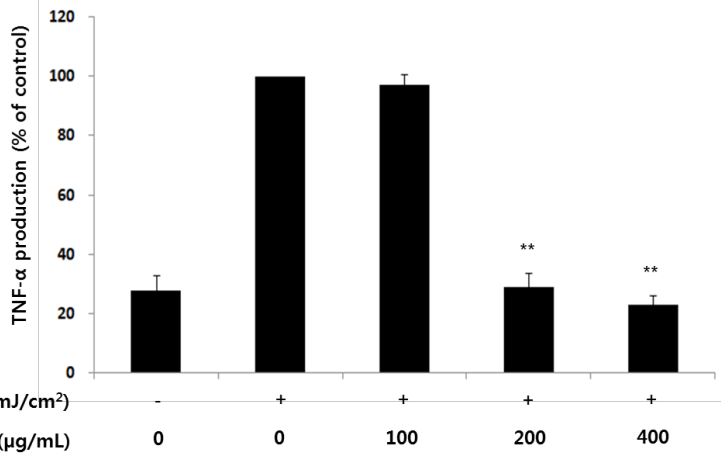

(B)

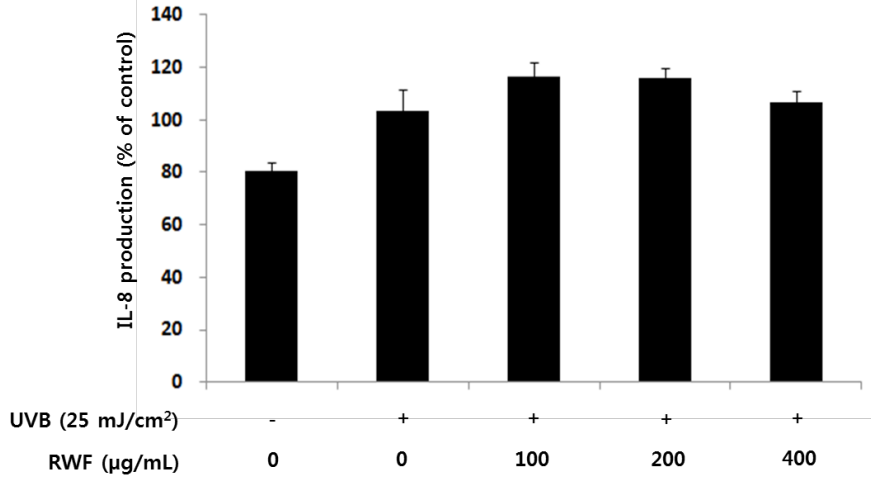

(C)

Fig. 3: Effect of Rhododendron weyrichii flower (RWF) extract on IL-6, TNF- $\alpha$, and IL-8 production in UVB-irradiated HaCaT cells. The cells were irradiated with $25 \mathrm{~mJ} / \mathrm{cm}^{2}$ of UVB only or with UVB plus various concentrations (100, 200, or $400 \mu \mathrm{g} / \mathrm{mL}$ ) of RWF extract for $24 \mathrm{~h}$. IL-6 (A), TNF- $\alpha$ (B), and IL-8 (C) production was determined by ELISA. The data represent the means \pm SD of quadruplicate experiments. ${ }^{*} \mathrm{p}<0.05, * * \mathrm{p}<0.01$ compared to UVB alone.

(A)
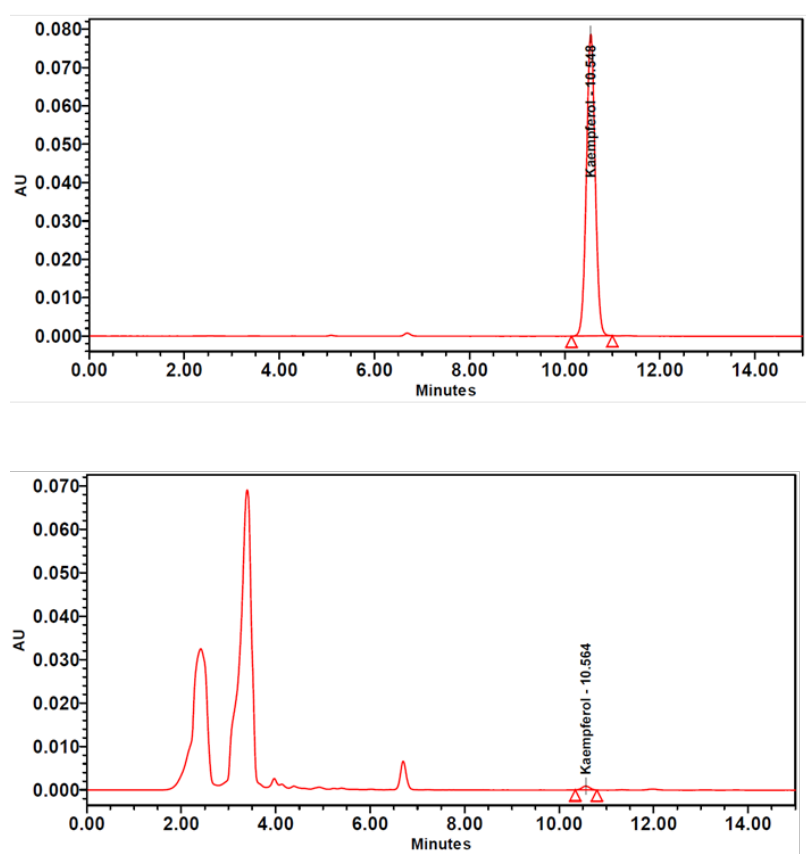

(B)
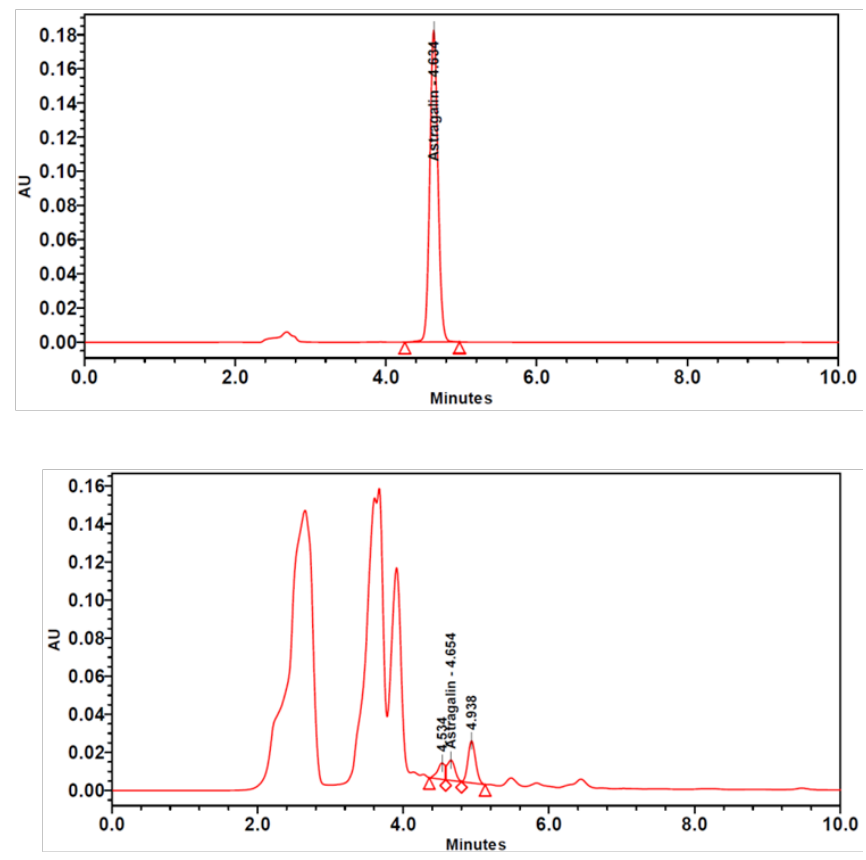

Fig. 4: HPLC chromatograms of kaempferol and astragalin of Rhododendron weyrichii flower (RWF) extract. (A) Kaempferol HPLC analysis of kaempferol standard (upper) and RWF extract (lower). (B) Astragalin HPLC analysis of astragalin standard (upper) and RWF extract (lower). 
Table 2: Results of human skin primary irritation test.

\begin{tabular}{|c|c|c|c|c|c|c|c|c|c|c|c|c|c|}
\hline \multirow{2}{*}{ No. } & \multirow{2}{*}{ Test material } & \multirow{2}{*}{ No. of responders } & \multicolumn{4}{|c|}{$48 \mathrm{~h}$} & \multicolumn{4}{|c|}{$72 \mathrm{~h}$} & \multicolumn{3}{|c|}{ Reaction Grade } \\
\hline & & & $1+$ & $2+$ & $3+$ & $4+$ & $1+$ & $2+$ & $3+$ & $4+$ & $48 \mathrm{~h}$ & $72 \mathrm{~h}$ & Mean \\
\hline 1 & RWF extract $(400 \mu \mathrm{g} / \mathrm{mL})$ & 0 & - & - & - & - & - & - & - & - & 0.0 & 0.0 & 0.0 \\
\hline 2 & Squalane (Negative control) & 0 & - & - & - & - & - & - & - & - & 0.0 & 0.0 & 0.0 \\
\hline
\end{tabular}

-: Not detected.

\section{ACKNOWLEDGMENTS}

This work was supported by the Academic and Research Institutions R\&D Program (C0516709) funded by the Small and Medium Business Administration (SMBA, Korea).

\section{REFERENCES}

Kim SB, Kang OH, Joung DK, Mun SH, Seo YS, Cha MR, Ryu SY, Shin DW, Kwon DY. Anti-inflammatory effects of tectroside on UVBinduced HaCaT cells. Int J Mol Med, 2013; 31:1471-1476.

Kim SB, Kim JE, Kang OH, Mun SH, Seo YS, Kang DH, Yang DW, Ryu SY, Lee YM, Kwon DY. Protective effect of ixerisoside A against UVB-induced proinflammatory cytokine production in human keratinocytes. Int J Mol Med, 2015; 35:1411-1418.

Ha SJ, Lee J, Kim H, Song KM, Lee NH, Kim YE, Lee H, Kim YH, Jung SK. Preventive effect of Rhus javanica extract on UVB-induced skin inflammation and photoaging. J Funct Foods, 2016; 27:589-599.

Park JH, Lee JE, Choi S, Park TH. Protective effects of silkworm hemolymph extract and its fractions on UV-induced photoaging. Biotechnol Bioproc Eng, 2017; 22:37-44.

Kim E, Hwang K, Lee J, Han SY, Kim EM, Park J, Cho JY. Skin Protective Effect of Epigallocatechin Gallate. Int J Mol Sci, 2018; 19: E173.

Janda J, Burkett NB, Blohm-Mangone K, Huang V, CurielLewandrowski C, Alberts DS, Petricoin EF $3^{\text {rd }}$, Calvert VS, Einspahr J, Dong Z, Bode AM, Wondrak GT, Dickinson SE. Resatorvid-based Pharmacological Antagonism of Cutaneous TLR4 Blocks UV-induced NF- $\kappa \mathrm{B}$ and AP-1 Signaling in Keratinocytes and Mouse Skin. Photochem Photobiol, 2016; 92:816-825.

Lembo S, Balato A, Di Caprio R, Cirillo T, Giannini V, Gasparri F, Monfrecola G. The Modulatory Effect of Ellagic Acid and Rosmarinic Acid on Ultraviolet-B-Induced Cytokine/Chemokine Gene Expression in Skin Keratinocyte (HaCaT) Cells. Biomed Res Int, 2014; 2014:346793.

Krolikiewicz-Renimel I, Michel T, Destandau E, Reddy M, André P, Elfakir C, Pichon C. Protective effect of a Butea monosperma (Lam.) Taub. flowers extract against skin inflammation: antioxidant, anti-inflammatory and matrix metalloproteinases inhibitory activities. J Ethnopharmacol, 2013; 148:537-543.

Yoichi W, Tamaki I, Sakaguchi S, Song JS, Yamamoto SI, Tomaru N. Population demographic history of a temperate shrub, Rhododendron weyrichii (Ericaceae), on continental islands of Japan and South Korea. Ecol Evol, 2016; 21:8800-8810.
Kim TM. 2015. The antioxidant, anti-inflammatory and whitening activities of an ethanol extract from leaves of Rhododendron weyrichii maxim. Seoul, Korea: Master's Thesis, Chung-Ang University.

Kim MJ, Kim SS, Yun SH, Kim SY, Hyun KH, Lee J, Lee NH, Hyun CG. Melanogenesis Inhibitory Activity of Rhododendron Weyrichii in Mouse B16 Melanoma Cells. Orient J Chem, 2016; 32:1899-1907.

Ito S, Wakamatsu K. Biochemical Mechanism of RhododendrolInduced Leukoderma. Int J Mol Sci, 2018; 19: E552.

Yoshikawa M, Sumikawa Y, Hida T, Kamiya T, Kase K, IshiiOsai Y, Kato J, Kan Y, Kamiya S, Sato Y, Yamashita T. Clinical and epidemiological analysis in 149 cases of rhododendrol-induced leukoderma. J Dermatol, 2017; 44:582-587.

Inoue M, Kikuchi K, Watabe A, Yamasaki K, Aiba S. The spectrophotometrical analysis of rhododendrol-induced leucoderma using a novel multispectral camera. Br J Dermatol, 2016; 175:334-339.

Kim MJ, Kim SJ, Kim SS, Lee NH, Hyun CG. Hypochoeris Radicata attenuates LPS-induced inflammation by suppressing P38, ERK, and JNK phosphorylation in raw 264.7 macrophages. EXCLI, 2014; 13:123-136

Yoon WJ, Ham YM, Yoo BS, Moon JY, Koh J, Hyun CG. Oenothera laciniata inhibits lipopolysaccharide induced production of nitric oxide, prostaglandin $\mathrm{E}_{2}$ and proinflammatory cytokines in RAW 264.7 macrophage. J Biosci Bioeng, 2009; 107:429-438.

Wang L, Zhu X, Lou X, Zheng F, Feng Y, Liu W, Feng F, Xie N. Systematic characterization and simultaneous quantification of the multiple components of Rhododendron dauricum based on high-performance liquid chromatography with quadrupole time-of-flight tandem mass spectrometry. J Sep Sci, 2015; 38:3161-3169.

Mok SY, Lee S. Identification of flavonoids and flavonoid rhamnosides from Rhododendron mucronulatum for albiflorum and their inhibitory activities against aldose reductase. Food Chem, 2013; 136:969974.

How to cite this article:

Yang E-J, Yun SH, Ko J-H, Kang H-K, Lee JN, Park S-M, Hyun C-G. Protective effect of Rhododendron weyrichii flower extract against UVB-induced proinflammatory cytokine production in human keratinocytes. J App Pharm Sci, 2019; 9(01): 015-019. 